\title{
Polska i polskość w tekstach kultury popularnej (na przykładzie wybranych piosenek)
}

\section{Poland and Polishness in the lyrics of popular culture (on the example of selected songs)}

\author{
|Małgorzata Latoch-Zielińska \\ Uniwersytet Marii Curie-Skłodowskiej, Lublin \\ IORCID: 0000-0002-2481-6683
}

\begin{abstract}
One of the key elements of building respect for such values as patriotism, freedom, tolerance is to learn, read, interpret at school the texts that these values represent, without excluding works belonging to popular culture, which is so close to young people. The article presents the results of the analysis of selected texts from the circle of popular culture (songs) in terms of the functioning of Polish and Polishness issues in them. Formulated conclusions may be helpful in designing education aimed at building multidimensional identity of young people.
\end{abstract}

Key words: patriotism, popular culture, song, identity, youth

Streszczenie: Jednym z kluczowych elementów budowania szacunku dla takich wartości jak patriotyzm, wolność, tolerancja jest poznawanie, czytanie, interpretacja w szkole tekstów, które te wartości reprezentują, bez wykluczania utworów przynależnych do kultury popularnej, która jest tak bliska młodzieży. W artykule przedstawiono wyniki analizy wybranych tekstów z kręgu kultury popularnej (piosenek) w aspekcie funkcjonowania w nich problematyki Polski i polskości. Sformułowane wnioski mogą być pomocne w projektowaniu edukacji nakierowanej na budowanie wielowymiarowej tożsamości młodych ludzi.

Słowa kluczowe: patriotyzm, kultura popularna, piosenka, tożsamość, młodzież

\section{Wokół pojęcia „polskość”}

Rozważania na temat miejsca Polski i polskości w tekstach piosenek należy rozpocząć od ustalenia znaczenia pojęcia polskość, ponieważ jest ono bardzo różnie rozumiane.Wojciech Chlebda stoi na stanowisku, iż

Dysponujemy ogromną liczbą poświadczonych tekstowo (a pewnie jeszcze większą wciąż nieodkrytych) opisowych eksplikacji polskości, rozsianych po literaturze pięknej, eseistyce historycznej, mowach i pismach politycznych, kazaniach i listach pasterskich, publicystyce (Chlebda 2017, 3). 
Autor na potwierdzenie swoich słów, przywołuje kilka powstałych na ten temat w ostatnich dziesięcioleciach publikacji.

Każda z tworzących te zbiory wypowiedzi zawiera - w tej czy innej, to mocno rozbudowanej, to, na odwrót, aforystycznej formie - eksplikowanie tego, jak dany autor rozumie znaczenia wyrazów Polska, Polak, polski, polskość, a więc jakie treści, emocje i oceny wiąże z pojęciem polskość (Chlebda 2017, 4).

Cytowany badacz dowodzi, iż polskość jest definiowalna, nie ma jednak wciąż jej definicji.

Omawiane pojęcie łączy się nierozerwalnie z kategorią narodu rozumianego jako wspólnota kultury. Franciszek Adamski zauważa, iż dość często polską kulturę narodową opisuje się jako

społecznie i funkcjonalnie spójny system wartości, norm, symboli oraz legitymizacji, stanowiący własność grupy społecznej określającej się jako polska, będący jej wytworem, a jednocześnie jej dziedzictwem, określający jej postawy i zachowania, stanowiący jedne z zasadniczych czynników jej integracji oraz podstawę społecznej identyfikacji jej członków (Adamski 2003, 214).

Niezwykle interesujące rozumienie polskości zaproponował Adam Szostkiewicz, który twierdzi, iż

to rzecz szersza niż romantyzm, katolicyzm, bohaterstwo wojenne, Bóg, honor i ojczyzna. Coś więcej niż tylko rytuały polskości. Polskość to dziś przede wszystkim pewna, jak by to powiedział nieodżałowany ks. Tischner, propozycja etyczna. Nie musimy jej przyjmować, ale możemy. Obejmuje język i kulturę, historię i pamięć, ale także cywilizację, obyczaj, kulturę masową, dostępną dla wszystkich (...) do polskości się dorasta i wchodzi, ale też się od niej odchodzi (...) polskość to także interakcja ze światem, dialog z kulturą powszechną. Nie tylko z Europą i Ameryką, także z nowymi aktorami na globalnej scenie, jak Indie, krąg muzułmański, nowa Afryka czy Chiny (Szostkiewicz 2010).

W podobnym tonie należy odczytać słowa Jana Pawła II, który pisał, iż „polskość to w gruncie rzeczy wielość i pluralizm, a nie ciasnota i zamknięcie" (Jan Paweł II 2005, 92).

\section{Polskość, patriotyzm, kultura}

Rozważając znaczenie pojęcia „polskość”, nie sposób pominąć dyskusji dotyczących współczesnego patriotyzmu. Tutaj przywołajmy Marcina Napiórkowskiego, który wprowadza do dyskursu o patriotyzmie dwa nowe pojęcia - „softpatriotyzm” i „turbopatriotyzm”.

Softpatriotyzm został zbudowany w opozycji do tradycyjnego polskiego patriotyzmu. Proponował także nową formę: wykorzystanie nowoczesnych narzędzi marketingu, happeningów ulicznych, nowych mediów (...) Turbopatriotyzm jest reakcją na softpatriotyzm (...) nie gardzi nowoczesnymi metodami docierania do odbiorców i mobilizowania ich do działania, postuluje jednak przy tym powrót do tradycyjnych wartości, przywracając niepodległości rolę centralnego zwornika tożsamości. Oglądany z tej perspektywy turbopatriotyzm okazuje się syntezą patriotycznej tradycji ze znienawidzonym przez siebie softpatriotyzmem (Napiórkowski 2019, 26-27). 
Cytowany autor uważa, iż tematem wiodącym polskiego patriotyzmu w jego „turbo odsłonie” jest niepodległość, traktowana jako wartość najwyższa, dodatkowo będąca ciągle w niebezpieczeństwie. Naszą historię widzimy bardzo wybiórczo, akcentując przede wszystkim kolejne zrywy niepodległościowe, bohaterską walkę o utrzymanie niezależności. Jesteśmy $\mathrm{z}$ natury narodem partyzanckim, dobrze sprawdzamy się $\mathrm{w}$ walce, oporze, nieposłuszeństwie wobec wrogich sił zewnętrznych i wewnętrznych. Trudno natomiast żyje się, gdy nie ma o co walczyć, bowiem „doskonale miewamy się tylko wówczas, gdy jesteśmy niezadowoleni. Z sukcesem czujemy się obco i nieswojo"(Napiórkowski 2019, 38). Napiórkowski twierdzi, iż trzeba zmienić język patriotycznej narracji, odejść od patosu i bohaterstwa. Współczesny patriotyzm powinien przejawiać się w obywatelskiej postawie. Na poparcie swojej tezy przywołuje deklarację Michała Rusinka, który uważa, iż „nowoczesny patriotyzm to obywatelskość - obowiązki i prawa, współodpowiedzialność za miejsce, w którym żyjemy, za kulturę, za język. Patriotyzm codzienności i pokoju, a nie wojny"(Napiórkowski 2019, 30).

Szczególnie trafna jest teza Napiórkowskiego dotycząca kultury jako obszaru konfliktu pomiędzy softpatriotyzmem a turbopatriotyzmem. Autor przywołuje tutaj znaną skądinąd funkcję kultury jako lustra, w którym odbiorca (literatury, filmów, gier komputerowych, mediów) chce znaleźć swoje odbicie. „W lustrze turbopatriotycznej kultury odbija się jednak specyficzny podmiot, oficjalnie posiadający tylko jedną cechę - polskość, a poza tym po prostu „normalny”. Za tą „normalnością” kryje się jednak wiele milczących przesądzeń"(Napiórkowski 2019, 45).

O niebezpieczeństwach takiego „wykorzystywania” kultury pisał swego czasu Wojciech Józef Burszta, który twierdził:

Pomysł na Polskę solidarną opartą na kulturze zdefiniowanej jako bezwzględne podporządkowanie się powszechnie stanowionej moralności zbiorowej, kulturze zamkniętej na inność i nietolerancyjnej, jest swoistym powrotem do wyobrażeń nijak nie przystających do sytuacji XXI wieku. Kultura tak rozumiana nie jest w stanie zmierzyć się z wyzwaniami, które nas czekają. Oferta, jaką się kieruje ku młodym, jest skrojona na nacjonalistyczną i ksenofobiczną miarę żywcem jakby przeniesioną z międzywojnia (Burszta 2007, 42).

Nie jest to odosobniona ocena. Jerzy Wiśniewski, omawiając koncepcję edukacji w ostatnim programie wyborczym PIS, zauważa, iż szkoła jest traktowana przez obecne władze przede wszystkim jako miejsce formowania postaw, dodajmy - wprost wpisujących się w turbopatriotyczne idee.

Jakie wzorce proponuje się młodym ludziom? Nie chodzi o rozwój, dobrobyt, zaangażowanie, współpracę, kulturę, środowisko itd. Lekarz, akademik, artysta, aktywista społeczny lub nauczyciel nie zasługują na taki szacunek i wsparcie jak funkcjonariusz służb. Ale to spójne z obrazem otaczającego świata, który atakuje wrogimi ideologiami, grozi wojnami, ogranicza suwerenność. (...)Tak więc mamy wizję państwa, które jest w przeróżny sposób zagrożone, trzeba być więc stale gotowym do obrony, a nawet poświęcenia życia (Wiśniewski 2019). 
Podsumowując zebrane powyżej stanowiska dotyczące polskości i związanych z nią kategorii, należy zauważyć, iż kluczowe dla podjętych w tym artykule rozważań wydaje się, że interesujące nas pojęcie mieści w sobie treści, emocje i oceny formułowane z pozycji osoby opisującej polskość, za takim też jego subiektywnym rozumieniem opowiada się autorka tekstu. Widzi tę kategorię jako pewien zbiór przekonań i uznawanych wartości, które wpływają na zachowanie jednostki wobec ojczyzny, jej historii, tradycji, kultury, a także wobec innych ludzi i świata.

\section{Polska i polskość we współczesnej piosence}

Hanna Mamzer zauważa:

W nowoczesności ukierunkowanej i właściwie definiowanej przez zmianę, tożsamość jest zadaniem, które każdy musi indywidualnie i świadomie wykonać (...). Dialogiczność tożsamości przyjmuje postać trzywarstwowej struktury: autorefleksji, uwzględnienia historii (czy szerzej: perspektywy czasowej) oraz dialogu z Innym (...). Taylor w Etyce autentyczności nazywa taki rodzaj tożsamości dialogicznym: „Jesteśmy podmiotami cielesnymi, żyjemy w warunkach dialogicznych, przeżywamy czas w specyficznie ludzki sposób, tzn. pojmujemy nasze życie jako opowieść łączącą przeszłość, skąd przybyliśmy, z naszymi przyszłymi projektami" (Mamzer 2007, 52-53).

W budowaniu tak rozumianej wielowymiarowej tożsamości mogą być bardzo pomocne teksty z kręgu kultury popularnej, a zwłaszcza piosenki. Wśród wielu rodzajów piosenek należy wyróżnić szczególnie te, w których najważniejszy jest tekst. Jan Poprawa nazywa je literackimi. Wiele z nich

żyje w świadomości społecznej nie tylko jako piosenki, są analizowane i interpretowane, funkcjonują w podręcznikach szkolnych, stanowiąc egzemplifikację problematyki związanej z między innymi takimi wartościami, jak wolność, bunt, patriotyzm, tolerancja, pokój, prawa człowieka, solidarność (Latoch-Zielińska 2016, 362).

Ograniczenia publikacyjne pozwalają na przywołanie tylko kilku przykładów współczesnych piosenek, w których pojawia się temat Polski, polskości czy Polaków. Należy zauważyć, iż wybrane utwory reprezentują bardzo różne gatunki muzyczne, znajdziemy wśród nich utwory rockowe, punk rockowe, rap czy poezję śpiewaną, co ma pokazać wielką różnorodność i obfitość tekstów podejmujących omawianą problematykę. Bardzo zróżnicowane jest również podejście do samego tematu, co oczywiście nie dziwi, bo tak jak w przypadku próby definiowania pojęcia polskość, każdy z przywołanych niżej tekstów stanowi swoistą eksplikację tego, jak dany autor rozumie znaczenia wyrazów Polska, Polak, polski, polskość, jakie treści, emocje i oceny wiąże z tymi pojęciami, wreszcie nie bez znaczenia jest często sytuacja polityczna, w której powstawał dany utwór i zakładany/ potencjalny odbiorca. Przywoływane teksty wpisują się w kilka sposobów postrzegania patriotyzmu. Nie wszystkie możemy w prosty sposób przyporządkować do kategorii wyróżnionych przez Napiórkowskiego. Znajdziemy 
wśród nich różne ujęcia polskości od afirmatywnych, przez dialogiczne, krytyczne aż do pełnych dezaprobaty. W artykule skupiono się na warstwie tekstowej wybranych utworów, nie zajmowano się warstwą muzyczną, której warto by poświęcić osobne rozważania.

O różnych wizjach patriotyzmu i Ojczyzny możemy mówić na przykładzie tekstów Marka Grechuty i Marii Peszek. Pierwszy z artystów zwraca się wprost do odbiorcy z wezwaniem „Masz obronić co najlepsze by służyło Polsce jeszcze" (Grechuta 1994). To słowa z piosenki Ojczyzna, utworu z kręgu poezji śpiewanej. Istotny jest tutaj fakt, iż pochodzi on z w pełni autorskiego albumu artysty „Dziesięć ważnych słów”(1994). Daniel Wyszogrodzki podkreśla:

nigdy wcześniej w jego twórczości inspiracje nie były tak bezpośrednio związane z polską rzeczywistością - głównie w jej kontekście społecznym i kulturowym, choć nietrudno doszukać się tu subtelnych aluzji politycznych. Stało się to za sprawą zmian, jakie dokonały się w kraju na początku lat dziewięćdziesiątych. Zrozumiałe, że artystę najbardziej interesowały konsekwencje tych zmian w duchowej sferze życia. Artysta mówi, że DZIESIĘĆ WAŻNYCH SŁÓW to „propozycja dla ludzi, którzy poszukują w życiu dróg i sięgają w tym celu po poezję". Określa swe dokonanie jako „dziesięć przykazań dla człowieka współczesnego” i nie zaprzecza, że pewna funkcja moralizatorska tych utworów była zamierzona (Wyszogrodzki).

Grechuta śpiewa o tym, czym naprawdę jest dla niego miłość do Ojczyzny. Patriotyzm według artysty polega na pielęgnowaniu naszej narodowej przynależności, odpowiedzialności za dorobek przeszłych pokoleń, „Dziś Ojczyzna jest w potrzebie czeka ciebie, wierzy w ciebie tysiąc lat historii patrzy w serce twe" (Grechuta 1994). Warto zwrócić uwage na słowa podkreślające szczególną rolę kultury w budowaniu i zachowaniu tożsamości: „Bez historii, mowy, sztuki, Bez mądrości tej z nauki naród się zamieni w bezimienny kraj" (Grechuta 1994). Autor w kolejnych wersach przekonuje odbiorcę, iż Ojczyzna stanowi źródło siły wywodzącej się właśnie z tradycji, wielkiej przeszłości, znakomitej, mądrej literatury.

Zupełnie inaczej rozumie swoje obowiązki wobec ojczyzny Maria Peszek, która uważa, iż „Lepszy żywy obywatel, niż martwy bohater” (Peszek 2012). Niewątpliwie utwór Sorry Polsko, uznawany przez rzesze odbiorców za obrazoburczy, podejmuje dyskusję z tradycyjnie rozumianym patriotyzmem, koniecznością poświęcenia życia za wolność kraju. Peszek wprost deklaruje:

Gdyby była wojna,

byłabym spokojna

Po kanałach z karabinem,

nie biegałabym

Nie oddałabym ci Polsko,

ani jednej kropli krwi

Sorry Polsko (Peszek 2012). 
Ważnym komentarzem do tak rozumianego patriotyzmu są słowa samej autorki:

Dla sporej części mojego pokolenia to jest chyba istotne. Chcielibyśmy traktować ojczyznę jako coś miłego, a nie jako upiora (...). A ciągle nam się wciska kult śmierci. Czas honoru. Ciągle stajemy wobec tych skrajnych, romantycznych roszczeń. „Oddaj życie!”. Wciąż wraca to absurdalne pytanie: „Czy oddałabyś życie?”. A mi się wydaje, że trupów było dosyć. Natomiast brakuje mi świadomie szczęśliwych Polaków (Peszek 2012).

Artystka przekonuje, iż dobry obywatel spełnia swoje obowiązki - płaci abonament, kupuje bilety na przejazd, uczestniczy w wyborach, dlatego apeluje:

nie każ walczyć, nie każ ginąć

Nie chciej Polsko mojej krwi (Peszek 2012).

Tego typu postawa jest zbieżna $\mathrm{z}$ formułą patriotyzmu obywatelskiego Michała Rusinka, czy - jak mówi socjolog Krystyna Szafraniec - z patriotyzmem pragmatycznym, czyli „możliwością realizowania we własnym kraju własnych życiowych celów” (Słomczyński 2013). Jednocześnie jest to dezaprobata dla obowiązku ofiary za ojczyznę, ciągłej gotowości do jej obrony.

W grupie kolejnych tekstów, których autorami są Muniek Staszczyk, Grzegorz Ciechowski, Kazik Staszewski, Adam Andrzej Ostrowski i Kora Jackowska, znajdujemy negatywny obraz Polski i Polaków. „Twój świat nie jest boski" (Staszczyk 2019), nie jest to jednak powód do tego, by opuścić kraj. Utwór Muńka Pola wywołał falę komentarzy. Jego premiera miała miejsce 3 czerwca 2019 roku - dzień przed 30. rocznicą wyborów 4 czerwca 1989 roku. Artysta w telewizyjnym wywiadzie mówi, iż jest

to piosenka o polskim stanie umysłu. O naszym smutku. Politycy, macherzy, zabrali nam zdrową normalną radość. To zostało ograbione. Piosenka jest o miłości, o dziewczynie (...). Wiadomo, że w wielu krajach są podziały. Ale jak tak patrzymy na nasz kraj, to jest trochę smutne. Politycy zabrali nam radość, wspólnotę (...). Ludzie żyją teraz w osobnych bańkach, i nikt z tej bańki nie chce wyjść. Na przykład ktoś ma bańkę totalnie konserwatywną, ktoś inny totalnie lewicową (...). Nie ma opcji, żeby wyjść w tych baniek i w jakiś sposób ze sobą pogadać. Ja jestem człowiekiem dialogu (Staszczyk 2019).

Tytułową Polę możemy uznać za personifikację Polski, Polaków, których artysta wzywa do obudzenia się, otrząśnięcia z mitów i błędnych przekonań.

Pola błagam obudź się

Sen o potędze skończył się

W swojej iluzji nie możesz trwać tak długo (Staszczyk 2019).

Autor zdaje sobie sprawę, iż otaczająca rzeczywistość jest daleka od ideału, każdy ma swoje własne problemy, ucieka od problemów innych, „zakrywa twarz”, udaje. Polska to „i ja i ty i on i ona i my i wy i oni” - podzieleni, pokłóceni, oddaleni, nierozumiejący się nawzajem, skupieni 
na sobie niczym tytułowi ludożercy z wiersza Tadeusza Różewicza. Taki obraz Polski kłóci się z afirmatywnym ukazywaniem ojczyzny i jej obywateli, blisko mu do „portretu” ojczyzny i jej chorób z Kazań Sejmowych Piotra Skargi. Jednak wciąż jest możliwość odrodzenia „O Pola nie, dasz radę wierzę w ciebie...”. Możemy w tych słowach znaleźć dalekie echo Mazurka Dąbrowskiego. Wymowę tekstu podkreśla i znacznie poszerza teledysk w reżyserii Katarzyny Sawickiej, którego fabuła obfituje w liczne symbole i metafory nawiązujące do najnowszej historii Polski.

„Nie ma dla mnie innych miejsc...” to stwierdzenie z utworu Nie pytaj o Polske Grzegorza Ciechowskiego. Zdaniem Adama Nowaka (lidera grupy Raz, Dwa, Trzy) teksty Ciechowskiego zawsze były o czymś, nigdy nie pozostawiały słuchacza obojętnym. Z pewnością tak jest w przypadku tego utworu. Ciechowski wylicza wiele narodowych wad, jednak nie ma zamiaru opuszczać ojczyzny, woli mieszkać w swoim kraju, nie zrażają go „brudne dworce, gdzie spotykam ją; tłumy, które cicho klną; pijak, który mruczy coś przez sen; Że póki my żyjemy ona żyje też" (Ciechowski 1986). Justyna Potasiak uważa, iż Nie pytaj o Polskę

to najpiękniejsza definicja patriotyzmu, jaką zna! często spotyka się z ludźmi, którzy ten utwór wskazują jako najpiękniej mówiący o miłości do Polski. Absolutnie deklasyfikuje wszelkie patetyczne do bólu pieśni, a jego siła tkwi w prostocie oraz w tym, że tak idealnie wpisuje się w nastroje naszego społeczeństwa. Takie zwyczajne, codzienne odczucia (Potasiak 2017).

Podkreślając fenomen tego tekstu, warto jeszcze przywołać słowa Zbigniewa Krzywańskiego:

Jeżeli poruszamy kwestię utworu Nie pytaj o Polskę, to rzeczywiście rzadko się zdarza, że artysta tak trudny temat ujmuje w tak nieprawdopodobny sposób, jak zrobił to Grzegorz Ciechowski. Dzisiaj na fali licytowania się na patriotyzm, sporów o to, z czego My jako Polacy powinniśmy być dumni, czy ze stosunku do naszej historii, która wbrew tym, którzy chcieliby widzieć nasz naród jako nieskazitelny, nie mający żadnych ciemnych kart w swojej historii, to jednak mimo wszystko te karty mamy (...). Podejście Grzegorza do swojej ojczyzny, wszystkiego co się w niej dzieje, było wypełnione pragnieniem wolności. Wszystko co się działo na świecie, rozpatrywał przez pryzmat wolności, bo stanowi ona podstawę bycia szczęśliwym. Zmieniał się przekaz, w międzyczasie upadł komunizm, natomiast Grzegorz poruszał w swoich tekstach nie tyle tematy polityczne, co miejsce człowieka w systemie (Krzywański 2013).

W zbliżonym do Ciechowskiego tonie mówi o Polsce Kazik Staszewski. Jej obraz w piosence Kultu Polska nie jest sielankowy.

Bałtyk śmierdzi ropą naftową

(...)

Po sobotnich balach chodniki zarzygane

(...)

Gdy wchodzę na kamienne schody

Zaczepia mnie pijanych meneli wielu 
Jutro spotkają się w kościele

(...)

Jest tak brudno i brzydko że pękają oczy (Staszewski 1987).

Staszewski bez ogródek wytyka rodakom pijaństwo, skłonność do przemocy, zakłamanie. Odrazę budzi obraz brudnych, brzydkich śmierdzących ulic, dworców, plaż. Słowa refrenu można odczytać jako przewrotną akceptację opisywanego stanu rzeczy:

Polska.

Mieszkam w Polsce.

Mieszkam w Polsce.

Mieszkam tu, tu, tu, tu (Staszewski 1987).

Refren Kazik wręcz wykrzykuje, jakby chciał podkreślić, iż nie wstydzi się tego, że jest Polakiem. Choć rodacy są pełni ułomności i wad, jest on częścią wspólnoty. Tu jest jego miejsce na ziemi. Jako Polak ma prawo do krytycznej oceny swojej ojczyzny, nie daje jednak, jak się wydaje, takiego prawa innym.

W dyskusję o Polsce i Polakach wpisuje się również hiphopowa piosenka pt. Kochana Polsko O.S.T.R-a. Jej autor, Adam Andrzej Ostrowski, w swojej biografii podkreśla, że hip-hop to jego pasja i praca. Tworząc kolejne „rymy”, czuje się za nie odpowiedzialny, ponieważ

słowa uwiecznione na taśmie, winylu czy kompakcie już zawsze będą odzwierciedleniem myśli, emocji, intelektu i uczuć. Tak powstaje coś w rodzaju pamiętnika, który jest odbiciem tego, kim byłem, kim jestem i kim mogę się stać, a każda płyta to następny rozdział (Ostrowski 2019, 102).

W Kochana Polsko Ostrowski z jednej strony deklaruje miłość do ojczyzny, z drugiej zaś rozczarowanie wobec samych Polaków.

Co jest?

To jest ta miłość, w tym jest ta miłość...

Kochana Polsko...

Dzięki za wszystko...

Od 22 lat...

W tym syfie...

Tak jest... (Ostrowski 2002).

Rozgoryczenie podkreślają między innymi wyrazy nacechowane negatywnie: syf, Judasz, frajerzy, bagno, samowolka. Jednak to nie zraża Ostrowskiego, Polska daje mu siłę. „Miłość we mnie wielka (...) Tu jest moje miejsce (...) choć idę pod prąd" - rapuje O.S.T.R.

Podobnie śpiewa Kora Jackowska „Tu nawet jak mnie kopią To kopią mnie swoi" (Jackowska 2005). Mogę mieć kłopoty, mogą mnie nie lubić, nawet prześladować, ale to:

Tu jest mój język

Tutaj jest mój świat

Możemy być dla siebie 
I bliscy i wrodzy

Ale w końcu z czasem

Wszystko się ułoży

Tu jest mój dom

Tutaj moja ziemia

Tutaj moje życie (Jackowska 2005).

Tu jest mój dom w niewyszukany, prosty sposób podkreśla więź każdej osoby z ojczyzną, miejscem, gdzie nawet porażki i upokorzenia jest łatwiej znieść, gdzie zawsze jest nadzieja na lepsze jutro, bo „w końcu z czasem wszystko się ułoży”. Ojczyzna zatem jawi się jako miejsce wyidealizowane.

Utworem, który niejako dopełnia opisywaną wyżej grupę tekstów, jest piosenka Jacka Kaczmarskiego A my nie chcemy uciekać stąd (muzyka i wykonanie Przemysław Gintrowski). Inspiracją dla tekstu był dramatyczny pożar szpitala psychiatrycznego w miejscowości Górna Grupa z 31 października na 1 listopada 1980 roku. Jedną z możliwych interpretacji tego uniwersalnego tekstu jest przyjęcie, iż płonący budynek to Polska. Wielu słuchaczy właśnie tak odczytywało ten tekst, dodatkowo w „domu dla psychicznie chorych" widziano nie ogarnięty pożarem szpital, tylko właśnie Polskę z czasów stanu wojennego. Należy jednak pamiętać, iż tekst ten Kaczmarski napisał przed jego wprowadzeniem, natomiast wydarzenia stanu wojennego nadały utworowi dodatkowej wymowy.

Kaczmarski opowiada o wydarzeniach niezwykle emocjonalnie, co dodatkowo podkreśla napięcie i grozę:

Ci przywiązani dymem materaców

Przepowiadają życia swego słowa

Nam pod nogami żarzą się posadzki

Deszcz iskier czerwonych osiada na głowach

Dym coraz gęstszy obcy ktoś się wdziera

A my wciśnięci w najdalszy sali kąt (Kaczmarski 1980).

Kiedy w końcu otwiera się droga ucieczki, padają zaskakujące słowa:

A my nie chcemy uciekać stąd!

A my nie chcemy uciekać stąd!

Krzyczymy w szale wściekłości i pokory

Stanął w ogniu nasz wielki dom!

Dom dla psychicznie i nerwowo chorych!(Kaczmarski 1980).

Przywoływane powyżej piosenki łączy przede wszystkim podjęcie dyskusji z utrwalonym w tradycji patriotycznej wyidealizowanym portretem ojczyzny i jej obywateli oraz formułowanych oczekiwań wynikających z długu wdzięczności wobec przodków. Z tekstów wyłania się model polskości rozumianej jako przyjęcie odpowiedzialności za swój kraj, nieuciekanie od problemów, mówienie otwarcie o bolączkach dnia codziennego, spełnianie zwykłych obywatelskich obowiązków, wreszcie spojrzenie do przodu, w przyszłość, oderwanie się od tego, co było, od rozpamiętywania dawnych porażek i chwil chwały. 
Na osobne omówienie zasługuje tzw. polski rap patriotyczny. Stanowi on ewenement na rynku muzycznym. Krótka kwerenda na portalach muzycznych przekonuje, iż zasoby tego typu utworów są bardzo duże. $\mathrm{Na}$ podkreślenie zasługuje łącząca te utwory stylistyka, bazująca na prostym przekazie, odwołująca się do polskich symboli narodowych, obowiązków wobec ojczyzny, podziękowania tym, którzy oddali życie za kraj. Wiele z tych utworów jest swoistym ocaleniem/przywróceniem pamięci o zapomnianych, często celowo, bohaterach najnowszej historii Polski. Można zaryzykować stwierdzenie, iż tego typu utwory realizują założenia turbopatriotyzmu. Zdecydowana ich większość powstaje w środowiskach skrajnie prawicowych, narodowościowych, identyfikujących polskość, patriotyzm m.in. z koniecznością zadośćuczynienia prześladowanym przedstawicielom podziemia antykomunistycznego. Jeden z raperów, Lukasyno, tak o tym mówi: „Najlepszą rzeczą, jaką możemy zrobić, by spłacić nasz dług wobec „Wyklętych”, to dbanie, aby pamięć o ich czynach i postawach przetrwała, ale była też inspiracją dla naszego i kolejnych pokoleń (...), obserwując dewaluację tradycyjnych wartości w zachodniej Europie, cieszę się, że w Polsce budzą się nastroje narodowościowe" (Kawczyńska 2017). Trzeba też podkreślić, że twórczość tego typu jest częścią większego zjawiska w popkulturze, swoistej mody na Żołnierzy Wyklętych:

Stają się [oni] idolami młodego pokolenia i często mówi się o nich młodzieżowym językiem (...), pojawiają się w piosenkach, na koszulkach, na muralach. O wyklętych śpiewali De Press, Paweł Piekarczyk, Czerwone Gitary, Sabaton. Z inspiracji Darka Malejonka powstał cały projekt poświęcony pamięci kobiet z oddziałów podziemia antykomunistycznego (Chojnowska 2017).

\section{O „Żołnierzach Wyklętych”, „Rotmistrzu Witoldzie Pileckim”,} „Nilu” czy „Ince” rapuje m.in. Tadek, czyli Tadeusz Polkowski, znany w Internecie jako Tadek Firma Solo:

To imię i nazwisko winno znać każde dziecko

Przypomnijmy o Rotmistrzu trzeba dać świadectwo,

On za Polskę walczył z armią bolszewicką i niemiecką (Polkowski 2012).

Widzę siłę w Twoich oczach, która naród Polski niosła,

Widzę w Tobie odwagę, chociaż nie jesteś dorosła,

Widzę w Tobie wielki honor, ojczyznę i Boga,

Chociaż pętlą się zaciska, krwawa wojenna pożoga,

Kiedy sen przychodzi, spotykam Cię Ineczko (Polkowski 2012).

Polkowski jest mocno zaangażowany w działalność „patriotyczną”, często bierze udział w różnego rodzaju spotkaniach kombatantów z młodzieżą, festiwalach. Traktuje to niemal jako misję:

Najważniejsze wydaje mi się jednak to, że ci ludzie, którzy dzięki tym tekstom dowiadują się, jaka była historia ich kraju czy miasta, zaczynają działać. Pielęgnują pamięć po tych, którzy walczyli, sprzątają ich pomniki, pamiętają o rocznicach, tworzą lub zapisują się do fundacji (Kawczyńska 2017). 
Wiele utworów z omawianego kręgu odwołuje się do innych bohaterów walk niepodległościowych. Przywołajmy tutaj jako egzemplifikację Apel poległych Konstruktora, tekst zbudowany w formie wyliczenia kolejnych miejsc, zdarzeń, osób, formacji wojskowych, które w jakiś sposób wiążą się z obroną ojczyzny, walką o wolną Polskę:

Za partyzantów oraz regularną armię,

Za oddziały w terenie, za Polską Husarię,

(...)

Za krew, za wolność, za dumę i honor,

Za Westerplatte i za tych co się bronią,

za rannych, za weteranów, co granic strzegli,

za wrzesień i powstanie, to apel poległych! (Konstruktor 2010).

Ważną cechą nie tylko polskiego rapu jest silny lokalny patriotyzm, identyfikacja z miejscem pochodzenia, zamieszkania, dzielnicą, w której dany artysta dorastał. Spośród wielu tekstów warto zauważyć Nie zapomnij skad jesteś - śląskiego rapera Miuosha, (feat. ${ }^{1}$ Paluch, Jr.Stress), akcentujący przywiązanie do miejsca swego pochodzenia i płynącą z tego dumę:

Tutaj się urodziłem, za to życie oddałbym bez pytań

Mam Śląsk przed oczami, kiedy za mikrofon chwytam, kiedy płynę po bitach

Ja i ta okolica, wiem, że to tylko tu i że tylko w Katowicach

$\mathrm{Tu}$, gdzie ulica nazywa Cię po imieniu

Gdzie kamień na kamieniu układały ojców ręce

Gdzie byś nie był, pamiętaj o pochodzeniu ziom, nie zapomnij skąd jesteś

(...)

Wszystkie ważne dla mnie dni wiążą się z tym miejscem,

tu uczyłem życia się, tutaj odnalazłem szczęście ...

I na drugim końcu świata będę dumny z pochodzenia,

Godny reprezentant kraju, nieważne na jakich ziemiach (Borycki, Paluszak,

Galiński 2011).

Miuosh wziął udział w spektaklu „Wujek 81. Czarna ballada”, który został przygotowany przez Teatr Śląski w Katowicach z okazji 35. rocznicy pacyfikacji kopalni Wujek. Epizod ten traktuje podobnie jak Tadek Firma Solo jako obowiązek do wypełnienia wobec starszego pokolenia, któremu zawdzięcza to, kim jest:

U mnie w rodzinie świadomość historyczna zawsze była i będzie istotna. Nauczyłem się nie odpuszczać. Dziadkowie, rodzice - wszyscy opowiedzieli mi po części tej historii, resztę pochłonąłem sam. Teraz czas na mnie - przekażę to dalej. Takich rzeczy nie można odpuszczać, zapominać. Takie rzeczy mogą wrócić, jeśli się o nich zapomni, odpuści. Podkreślał, że nie chciał, aby była to „atrakcyjna forma edukacji historycznej", tylko spektakl, który mocno z tej historii czerpie (Kawczyńska 2017).

O historycznym dziedzictwie i wynikających z niego obowiązkach wobec Polski rapuje Majsi w utworze Patriot oraz Evident w piosence Bóg,

${ }^{1}$ Featuring, w skrócie feat. lub ft. (pol. z udziałem, gościnnie, z gościem) 
Honor, Ojczyzna. Oba teksty łączy odwoływanie się do utrwalonego w tradycji obrazu niezwyciężonego Polaka, obrońcy polskiej ziemi przez tysiące lat, mającego „krzyż wyryty na sercu” i tylko jedno marzenie - „życie dla wolnej Polski” (Majsi 2010), dumnie i z honorem noszącego „herb Ojczyzny, Bo stworzyły go tylko rany i blizny" (Evident 2011).

Wielu autorów z tego kręgu wykorzystuje jako jeden z wyznaczników polskości barwy narodowe. Taki zabieg zastosowano m.in. w piosence Mam biało- czerwone serce:

Mam biało-czerwone serce, barwy ojczyste.

Nikt mi tego nie zabierze, po polsku myślę.

Nikt mi tego nie zabierze, po polsku piszę.

To dla tych, którzy przelali krew za ojczyznę (Majewski (4P) 2008).

Znowu zauważamy powiązanie patriotycznej postawy z wdzięcznością dla przeszłych pokoleń, dla tych, którzy zginęli. Raper wymienia kolejno trudne momenty polskiej tysiącletniej historii: „Wojny, zabory, pokolenia w niewoli". Dalej przekonuje, że trzeba nie tylko oddać bohaterom należny hołd, ale też w razie potrzeby „stanąć do walki Wysłać na wojnę syna”.

Prawdziwy patriota kocha Polskę bezwarunkowo, mimo wielu jej wad, niedoskonałości. Taka postawa jest wspólna dla większości przywołanych tekstów, szczególnie zaś wybrzmiewa w piosence zespołu Zipera Patriota:

kocham ten kraj,

kocham bez przyczyny,

Który na barkach swych nosi, znosi ból i brudne czyny...

Kraj w kształcie serca, tu zawsze tkwimy,

Ten kawałek dla Polaków, dla Polskiej rodziny,

To Patriota, jego posąg na wagę złota (Zipera 2004).

W utworze mającym kształt rapowanej opowieści pada wiele gorzkich słów na temat współczesnej Polski, Polaków, elit politycznych. Przekaz muzyczny został dodatkowo wzmocniony w teledysku do utworu, w którym wykorzystano materiały opracowane przez Muzeum Powstania Warszawskiego.

\section{Uwagi na zakończenie}

Cytowany już wyżej Wojciech Józef Burszta podkreśla:

coraz mniej w naszym życiu jest miejsca na tradycję, na odwoływanie się do utrwalonych wartości, przekazywanych z pokolenia na pokolenie, że coraz trudniej znaleźć oparcie dla własnej tożsamości w tym, co minione. (...) Kultura popularna tworzy wizerunek nowego typu człowieka idealnego, nieodmiennie skupionego na pielęgnowaniu własnej - rzeczywistej lub konstruowanej - młodości, i posłusznym ciele. Namysł nad światem, a zwłaszcza nad przeszłością, jest rzeczą niemodną (Burszta 2007, 107).

Przywołane teksty, zwłaszcza z kręgu patriotycznego rapu, zdają się jednak przeczyć tej tezie. Wszystkie są bardzo mocno osadzone w tradycji 
właśnie, odwołują się do ojczyzny jako wartości nadrzędnej. W zróżnicowany sposób traktują patriotyzm, proponują inny sposób jego wyrażania, mówią o Polsce i polskości, używając całego repertuaru środków wyrazu, bardzo często otwarcie z tradycyjnym ujęciem polemizują. Można pokusić się o przypisanie przywołanych utworów do kategorii wyróżnionych przez Napiórkowskiego, lokując patriotyczny rap w obszarze turbopatriotyzmu, zaś do nurtu softpatriotyzmu zaliczyć zdecydowaną większość pozostałych, gdzieś pomiędzy pozostawiając piosenki Grechuty i Kaczmarskiego. Wydaje się, iż temat ten dla kultury popularnej nie jest jeszcze wyczerpany czy zużyty. Liczba utworów zdecydowanie to potwierdza.

Wymienione $\mathrm{w}$ artykule piosenki mogą być interesujące dla polonisty z kilku powodów: zwracają uwagę swoją formą językową, reprezentują wyznawane przez autorów poglądy, są świadectwem czasów, w których powstały. Z całą pewnością teksty te mogą zostać wykorzystane w dialogu z uczniami na temat współczesnego rozumienia patriotyzmu, polskości, refleksji nad kondycją Polski i Polaków, znaczenia tradycji w budowaniu wielowymiarowej tożsamości.

Organizując nowoczesne „Lekcje Polski(ego)”, warto pamiętać o wskazówkach Jeromego Brunera, który podkreślał znaczenie idei

sprawstwa: zwiększania stopnia zarządzania własną aktywnością umysłową; refleksji: nie mechanicznego „wkuwania na pamięć”, ale pojmowania sensu przyswajanego przedmiotu, uczenie się ze zrozumieniem; współpracy: dzielenia się wiedzą przez osoby zaangażowane w nauczanie i uczenie się. Umysł znajduje się w głowie, ale także w interakcji z innymi; wreszcie kultury, sposobu życia i myślenia, który konstruujemy, negocjujemy, poddajemy instytucjonalizacji, by wreszcie (ustaliwszy wszystkie te sprawy) - dla własnego pokrzepienia nazwać go „rzeczywistością” (Bruner 2006, 126).

Synergia działań wskazanych przez Brunera może ułatwić pracę nie tylko z tekstami piosenek z polskością $\mathrm{w}$ temacie, jednak $\mathrm{w}$ ich przypadku może być szczególnie efektywna.

\section{Bibliografia}

Adamski Franciszek, 2003, Tożsamość narodu przez kulturę, w: Kultura - wartości - kształcenie, Kubinowski D. (red.), Toruń, s. 214.

Błaszkiewicz Tomasz, Republika marzeń [online], https://cdn.ug.edu.pl/149/ republika-marzen/, [dostęp: 10.02.2020].

Borycki Miłosz, Paluszak Łukasz, Galiński Marcel, Nie zapomnij skąd jesteś, Miuosh (feat. Paluch, Jr.Stress) [online], http://www.tekstyhh.pl/index. php/Miuosh/Nie-zapomnij-skad-jestes-feat.Paluch-Jr.Stress.html, [dostęp: 10.02.2020].

Bruner Jerome, 2006, Kultura edukacji, Brzostowska-Tereszkiewicz T. (przeł.), Kraków.

Burszta Wojciech Józef, 2007, Tożsamość $w$ wojnie kultur, w: W poszukiwaniu tożsamości. Humanistyczne rozważania interdyscyplinarne, 2007, Mamzer H. (red.), Poznań, s. 42. 
Chojnowska Katarzyna, Moda na Żołnierzy Wyklętych? „Gdy w 2002 r. chcieliśmy ich upamiętnić, sami byliśmy wyklęci" [online], https://tygodnik. tvp.pl/29280483/moda-na-zolnierzy-wykletych-gdy-w-2002-r-chcielismy-ichupamietnic-sami-bylismy-wykleci, [dostęp: 10.02.2020].

Chlebda Wojciech, Czy polskość jest (słownikowo) definiowalna?, SPRAWY NARODOWOŚCIOWE Seria nowa / NATIONALITIES AFFAIRS New series, $49 / 2017$.

Ciechowski Grzegorz, Nie pytaj o Polske [online], https://www.tekstowo.pl/ piosenka,obywatel_gc,nie_pytaj_o_polske.html, [dostęp: 10.02.2020].

Evident, Bóg, Honor, Ojczyzna [online], https://www.tekstowo.pl/ piosenka, evident,bog honor ojczyzna.html, [dostęp: 10.02.2020].

Grechuta Marek, Ojczyzna [online], https://ising.pl/marek-grechuta-ojczyznatekst, [dostęp: 10.02.2020].

Jacek Żakowski z Maria Peszek o Polsce i nowej płycie [online], https://www.polityka.pl/tygodnikpolityka/kultura/1530689,1,jacek-zakowskiz-maria-peszek-o-polsce-i-nowej-plycie.read, [dostęp: 10.02.2020].

Jackowska Olga, Maanam, Tu jest mój dom [online], https://www.tekstowo.pl/ piosenka,maanam,tu jest moj_dom.html, [dostęp: 10.02.2020].

Jan Paweł II, 2005, Pamięć i tożsamość, Kraków.

Kaczmarski Jacek, A my nie chcemy uciekać stąd [online], https://www.kaczmarski.art.pl/tworczosc/wiersze/a-my-nie-chcemy-uciekacstad/, [dostęp: 10.02.2020].

Kawczyńska Marta, 2017, Moda czy potrzeba serca, czyli biało-czerwony rap [online], https://tygodnik.tvp.pl/29116361/moda-czy-potrzeba-serca-czylibialoczerwony-rap [dostęp: 10.02.2020].

Konstruktor, Apel poległych [online], https://www.tekstowo.pl/ piosenka,konstruktor,apel_poleglych.html, [dostęp: 10.02.2020].

Latoch-Zielińska Małgorzata, 2016, „W nieugiętym proteście przeciw złu kryje się cała sól życia”. Protest songi w tradycji kulturowej i przestrzeni edukacyjnej, w: Myrdzik B., Morawska I., Latoch-Zielińska M., Przestrzenie rzeczywiste i wyobrażone. Szkice i studia z edukacji polonistycznej. O roli kulturowego doświadczenia przestrzenności, Lublin, s. 362.

Majewski Przemysław (4P), Mam biało - czerwone serce [online], https://www.tekstowo.pl/piosenka,4p,mam bialo_czerwone serce.html, [dostęp: 10.02.2020].

Majsi, Patriot [online], https://www.tekstowo.pl/piosenka,majsi,patriot.html, [dostęp: 10.02.2020].

Mamzer Hanna, 2007, Narracyjne formy tożsamości, w: W poszukiwaniu tożsamości. Humanistyczne rozważania interdyscyplinarne, Mamzer $\mathrm{H}$. (red.), Poznań.

Muniek Staszczyk w studiu Dzień Dobry TVN [online], https://dziendobry.tvn. pl/a/muniek-staszczyk-i-pola-premiera-piosenki-i-teledysku-wideo, [dostęp: 10.02.2020]. 
Napiórkowski Marcin, 2019, Turbopatriotyzm, Wołowiec.

O.S.T.R., Kochana Polsko [online], https://teksciory.interia.pl/o-s-t-r-kochanapolsko-tekst-piosenki,t,131516.html, [dostęp: 10.02.2020].

OSTR, Ostrowski Adam Andrzej, Brzydki, zły i szczery, [ebook] Warszawa 2019

Peszek Maria, Sorry Polsko [online], https://www.tekstowo.pl/piosenka,maria peszek,sorry_polsko.html, [dostęp: 10.02.2020].

„Pola”: Próba zaakceptowania siebie. Nowy teledysk Muńka Staszczyka [online], https://papaya.rocks/pl/people/pola-proba-zaakceptowania-siebie-teledyskmunka-staszczyka, [dostęp: 10.02.2020].

Polkowski Tadeusz, Inka [online], https://www.tekstowo.pl/piosenka,tadek firma solo,inka.html, [dostęp: 10.02.2020].

Polkowski Tadeusz, Rotmistrz Witold Pilecki [online], https://www.tekstowo. $\mathrm{pl} /$ piosenka,tadek firma solo, rotmistrz witold_pilecki.html, [dostęp: 10.02.2020].

Poprawa Jan, Porozmawiajmy o słowie $w$ piosence [online], https://www.strefapiosenki.pl/aktualnosci/item/135-porozmawiajmy-o-slowiew-piosence, [dostęp: 10.02.2020].

Potasiak Justyna, Obywatel Grzegorz Ciechowski [online], http://kulturadogorynogami.pl/2017/08/29/obywatel-grzegorz-ciechowski/, [dostęp: 10.02.2020].

Raz Dwa Trzy w utworach Grzegorza Ciechowskiego i Republiki [online], https://kultura.onet.pl/muzyka/wiadomosci/raz-dwa-trzy-w-utworachgrzegorza-ciechowskiego-i-republiki/qzc15gn, [dostęp: 10.02.2020].

Słomczyński Tomasz, Jak młodzi rozumieja patriotyzm? Rozmowa z socjologiem [online], https://dziennikbaltycki.pl/jak-mlodzi-rozumieja-patriotyzmrozmowa-z-socjologiem/ar/883496, [dostęp: 10.02.2020].

Staszczyk Muniek, Pola [online], https://www.tekstowo.pl/piosenka,muniek staszczyk, pola.html, [dostęp: 10.02.2020].

Staszewski Kazik, Polska [online], https://www.tekstowo.pl/piosenka,kult,polska. html, [dostęp: 10.02.2020].

Szostkiewicz Adam, Polskość i inne ości, „Polityka” 28.2010 (2764) z dnia 10.07.2010 [online], https://www.polityka.pl/tygodnikpolityka/ kraj/1507074,1,co-to-znaczy-byc-polakiem.read [dostęp: 13.12.2019].

Wiśniewski Jerzy, Ekspert o edukacji w programie PiS: To wbrew światowym trendom [online], https://www.polityka.pl/tygodnikpolityka/ spoleczenstwo/1927236,1, ekspert-o-edukacji-w-programie-pis-to-wbrewswiatowym-trendom.read, [dostęp: 10.02.2020].

Wyszogrodzki Daniel, Marek Grechuta - Dziesięć ważnych słów [online], https:// www.poezjaspiewana.pl/marek-grechuta-cd/1509-marek-grechuta-dziesiecwaznych-slow-cd.html, [dostęp: 10.02.2020].

Zipera, Patriota [online], https://www.tekstowo.pl/piosenka,zipera,patriota.html, [dostęp: 10.02.2020]. 


\section{O Autorce}

Małgorzata Latoch-Zielińska, dr hab., prof. UMCS. Pracownik naukowy Instytutu Filologii Polskiej UMCS w Lublinie. Autorka ponad 90 publikacji w tomach zbiorowych i czasopismach z dziedziny dydaktyki języka polskiego i edukacji kulturalnej, ewaluacji i diagnostyki szkolnych osiągnięć uczniów, e-learningu, wykorzystania technologii informacyjno-komunikacyjnych w procesie kształcenia. Współautorka monografii: Przestrzenie rzeczywiste i wyobrażone. Szkice i studia z edukacji polonistycznej. O roli kulturowego doświadczenia przestrzenności oraz Przestrzenie rzeczywiste i wyobrażone. Metodyczny wielogłos o różnych przestrzeniach. Redaktor monografii Nowoczesna edukacja kulturalna, współredaktorka siedmiu monografii, w tym czterech z serii „Nowoczesność i tradycja w edukacji polonistycznej". 